(3) Aluminum nitrate spectra are dominated by the $303-\mathrm{nm}$ absorption peak, which is a direct function of $\mathrm{NO}_{3}{ }^{-}$concentration. No maximum at $240 \mathrm{~nm}$ is observed.

(4) $\mathrm{Cl}^{-}$and $\mathrm{ClO}_{4}^{-}$do not replace inner-sphere groups.

(5) Equivalent conductance measurements support the conclusions of the spectroscopic investigation.
Acknowledgment. The authors are pleased to acknowledge the support of the Office of Naval Research. This research was done under Grant No. N00014-75-C-0799 NR 036-106.

Registry No. $\mathrm{AlCl}_{3}, 7446-70-0 ; \mathrm{Al}\left(\mathrm{ClO}_{4}\right)_{3}, 14452-39-2 ; \mathrm{Al}_{2}\left(\mathrm{SO}_{4}\right)_{3}$, 10043-01-3; $\mathrm{Al}\left(\mathrm{NO}_{3}\right)_{3}, 13473-90-0$.

Contribution from the Institut für Anorganische Chemie,
Universität Regensburg, D-8400 Regensburg. Federal Republic of Germany

\title{
Photooxidation of 1,2-Dithiolene Complexes of Nickel, Palladium, and Platinum in Chloroform
}

\author{
ARND VOGLER* and HORST KUNKELY
}

Received June 15, 1981

\begin{abstract}
The photochemistry of the following 1,2-dithiolene complexes has been investigated. $M\left(\mathrm{~S}_{2} \mathrm{C}_{2} \mathrm{R}_{2}\right)_{2}{ }^{2}: \mathrm{M}=\mathrm{Ni}, \mathrm{Pd}, \mathrm{Pt}, \mathrm{R}$ $=\mathrm{CN}, z=2-, 1-; \mathrm{M}=\mathrm{Ni}, \mathrm{Pt}, \mathrm{R}=\mathrm{C}_{6} \mathrm{H}_{5}, z=0 ; \mathrm{M}=\mathrm{Ni}, \mathrm{R}=\mathrm{C}_{6} \mathrm{H}_{5}, z=1-$. These complexes were not light sensitive in most solvents such as acetonitrile. Those complexes which are oxidized at potentials between $E_{1 / 2}=0.1$ and $0.5 \mathrm{~V}$ vs. $\operatorname{SCE}\left(\mathrm{M}=\mathrm{Ni}, \mathrm{Pd}, \mathrm{Pt}, \mathrm{R}=\mathrm{CN}, z=2-; \mathrm{M}=\mathrm{Ni}, \mathrm{R}=\mathrm{C}_{6} \mathrm{H}_{5}, z=1-\right.$ ) were photooxidized in $\mathrm{CHCl}_{3}$ with light of wavelengths between 300 and $350 \mathrm{~nm}$. The other complexes which are oxidized at higher potentials are not light sensitive in $\mathrm{CHCl}_{3}$. It is suggested that the reactive excited state is of the charge-transfer-to-solvent (CTTS) type. The energy of this state depends only on the redox potentials of the complex and the solvent. When $\mathrm{CHCl}_{3}$ as solvent was replaced by the stronger oxidant $\mathrm{CCl}_{4}$, the photoactive wavelength region was shifted to the red. It was blue shifted when the weaker oxident $\mathrm{CH}_{2} \mathrm{Cl}_{2}$ was used. The CTTS states may be reached by internal conversion from higher intramolecular excited states. Direct light absorption by CTTS bands is not necessary to initiate the photooxidation.
\end{abstract}

\section{Introduction}

The photooxidation of coordination compounds may occur by quite different mechanisms. Bimolecular electron transfer from electronically excited transition-metal complexes to reducing agents has been extensively investigated recently. ${ }^{1,2}$ Another example is the photooxidation of certain cyanide complexes in aqueous solution accompanied by the production of solvated electrons. ${ }^{3,4}$ However, the majority of photooxidations of a great variety of transition-metal complexes has been observed in halocarbon solvents; where solvent molecules act as electron acceptors. ${ }^{5-10}$ Although charge-transfer-tosolvent (CTTS) states may be important in some cases, $5,6,9$ the nature of the photoactive excited states does not seem to be

(1) Whitten, D. G. Acc. Chem. Res. 1980, 13, 83.

(2) Balzani, V.; Bolletta, F.; Gandolfi, M. T.; Maestri, M. Top. Current Chem. 1978, 75, 1.

(3) (a) Waltz, W. L.; Adamson, A. W. J. Chem. Phys. 1969, 73, 4250. (b) Waltz, W. L.; Adamson, A. W.; Fleischauer, P. D. J. Am. Chem. Soc. $1967,89,3923$.

(4) Kalisky, O.; Shirom, M. J. Photochem. 1977, 7, 215 and references cited therein.

(5) (a) Brand, J. C. D.; Snedden, W. Trans. Faraday Soc. 1957, 53, 894. (b) Traverso, O.; Scandola, F. Inorg. Chim. Acta 1970, 4, 493

(6) Bock, C. R.; Wrighton, M. S. Inorg. Chem. 1977, 16, 1309.

(7) Mann, K. R.; Gray, H. B.; Hammond, G. S. J. Am. Chem. Soc. 1977, $99,306$.

(8) (a) Schwendiman, D. P.; Zink, J. I. J. Am. Chem. Soc. 1976, 98, 1248 , 4439. (b) Liu, P.-H.; Zink, J. I. Ibid. 1977, 99, 2155.

(9) (a) Miessler, G. L.; Stuky, G.; Smith, T. P.; Given, K. W.; Palazotto, M. C.; Pignolet, L. H. Inorg. Chem. 1976, 15, 1982. (b) Given, K. W.; Mattson, B. M.; McGuiggan, M. F.; Miessler, G. L.; Pignolet, L. H. J. Am. Chem. Soc. 1977, 99, 4855. (c) Given, K. W.; Mattson, B. M. Pignolet, L. H. Inorg. Chem. 1976, 15, 3152. (d) Miessler, G. L. Zoebisch, E.; Pignolet, L. H. Ibid. 1978, 17, 3636.

(10) (a) Vogler, A.; Losse, W.; Kunkely, H. J. Chem. Soc., Chem. Commun. 1979, 188. (b) Vogler, A.; Kunkely, H. Angew. Chem., Int. Ed. Engl. 1980, 19, 221. (c) Vogler, A.; Kunkely, H. J. Am. Chem. Soc. 1981 103, 1559. (d) Vogler, A.; Kunkely, H. Angew. Chem., Int. Ed. Engl. 1981,20 , in press. very clear. The present study may contribute to a better understanding of these photooxidations.

For our investigation we selected 1,2-dithiolene complexes ${ }^{11}$ of $\mathrm{Ni}, \mathrm{Pd}$, and Pt. This choice was guided by the following considerations. By a variation of the metal, the dithiolene ligand, and the charge of the complex, its electronic structure can be altered to a great extent. It was expected that such changes would influence the photochemical behavior considerably and lead to a correlation between electronic structure and photoreactivity.

Another interesting aspect of the present study is the growing interest in coordination compounds with sulfurcoordinating ligands ${ }^{12}$ due to their importance in biological systems. So far only a few investigations of the photochemistry of sulfur-containing complexes have been carried out ${ }^{8,9,13}$ although such complexes are known to participate in photosynthesis. $^{12}$

\section{Experimental Section}

Materials. The complexes $\left[\mathrm{N}\left(\mathrm{C}_{2} \mathrm{H}_{5}\right)_{4}\right]_{2}\left\{\mathrm{M}\left[\mathrm{S}_{2} \mathrm{C}_{2}(\mathrm{CN})_{2}\right]_{2}\right\}$, with $\mathrm{M}$ $=\mathrm{Ni}_{1}{ }^{14} \mathrm{Pd},{ }^{19}$ and $\left.\mathrm{Pt},{ }^{14}\left\{\mathrm{M}\left[\mathrm{S}_{2} \mathrm{C}_{2}\left(\mathrm{C}_{6} \mathrm{H}_{5}\right)_{2}\right]\right]_{2}\right\}$, with $\mathrm{M}=\mathrm{Ni}, \mathrm{Pt},{ }^{16}$ and $\left[\mathrm{N}\left(\mathrm{C}_{2} \mathrm{H}_{5}\right)_{4}\right]\left\{\mathrm{Ni}\left[\mathrm{S}_{2} \mathrm{C}_{2}\left(\mathrm{C}_{6} \mathrm{H}_{5}\right)_{2}\right]_{2}\right\}^{17}$ were prepared according to published procedures. Their electronic absorption spectra agreed well with those reported previously. ${ }^{16-19}$ All solvents used in the photochemical

(11) (a) McCleverty, J. A. Progr. Inorg. Chem. 1968, 10, 49. (b) Burns, R. P.: McAuliffe, C. A. Adv. Inorg. Chem. Radiochem. 1979, 22, 303.

(12) Holm, R. H. Acc. Chem. Res. 1977, 10, 427 and references cited therein.

(13) Adamson, A. W. Pure Appl. Chem. 1979, 51, 313.

(14) Billig, E.; Williams, R.; Bernal, I.; Waters, J. H.; Gray, H. B. Inorg. Chem. 1964, 3, 663

(15) Bähr, G.; Schleitzer, G. Chem. Ber. 1957, 90, 438.

(16) Schrauzer, G. N.; Mayweg, V. P. J. Am. Chem. Soc. 1965, 87, 1483.

(17) Davison, A.; Edelstein, N.; Holm, R. H.; Maki, A. H. Inorg. Chem. $1963,2,1227$

(18) Shupack, S. I.; Billig, E.; Clark, R. J. H.; Williams, R.; Gray, H. B. J. Am. Chem. Soc. 1964, 86, 4594. 


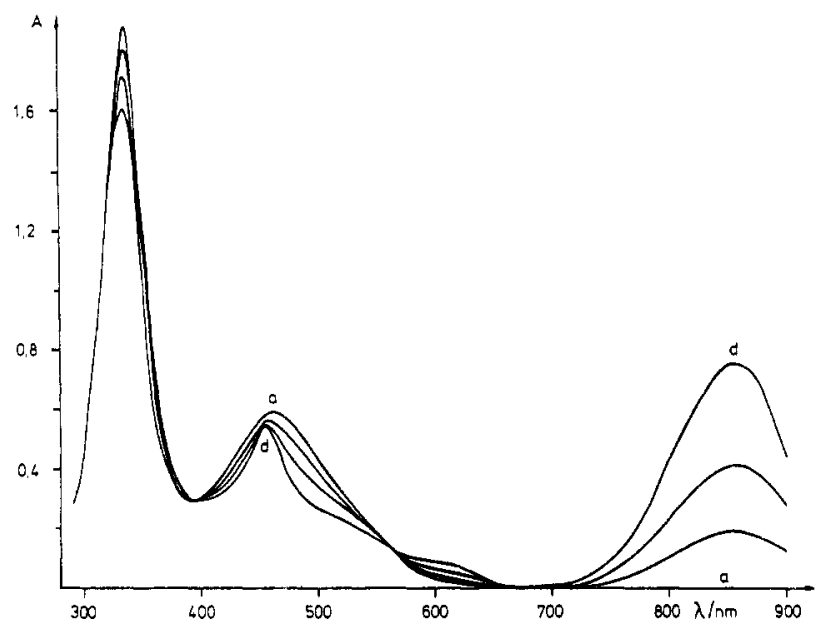

Figure 1. Spectral changes during the photooxidation of $1.39 \times 10^{-4}$ $\mathrm{M}\left[\mathrm{N}\left(\mathrm{C}_{2} \mathrm{H}_{5}\right)_{4}\right]_{2}\left[\mathrm{PtS}_{4} \mathrm{C}_{4}(\mathrm{CN})_{4}\right]$ in $\mathrm{CHCl}_{3}$ at (a) 0 and (d) 20 -min irradiation time, $\lambda_{\mathrm{irr}}=333 \mathrm{~nm}$, and $1-\mathrm{cm}$ cell.

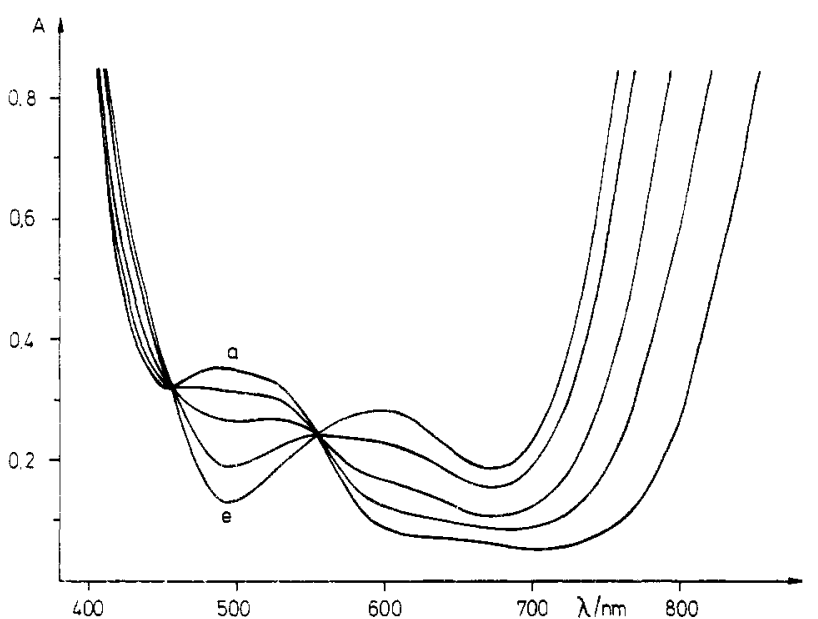

Figure 2. Spectral changes during the photooxidation of $1.84 \times 10^{-4}$ $\mathrm{M}\left[\mathrm{N}\left(\mathrm{C}_{2} \mathrm{H}_{5}\right)_{4}\right]\left[\mathrm{NiS}_{4} \mathrm{C}_{4}\left(\mathrm{C}_{6} \mathrm{H}_{5}\right)_{4}\right]$ in $\mathrm{CHCl}_{3}$ at (a) 0 and (e) 18 -min irradiation time, $\lambda_{\mathrm{irr}}>340 \mathrm{~nm}$, and $1-\mathrm{cm}$ cell.

experiments were Spectro grade. Purification of the solvents by chromatography $\left(\mathrm{Al}_{2} \mathrm{O}_{3}\right)$ and distillation from molecular sieves (5 $\AA$ ) did not affect the results.

Photolyses. The light source was a high-pressure mercury lamp Osram HBO $200 \mathrm{~W} / 2$. The following Schott interference filters of the type PIL were used for the irradiation at selected wavelengths: $313,333,366,406$, and $436 \mathrm{~nm}$. The photolyses were carried out at room temperature in 1 - and $10-\mathrm{cm}$ spectrophotometer cells. For quantum yield determinations the complex concentrations were such as to have essentially complete light absorption. The total amount of photolysis was limited to less than $5 \%$ to avoid light absorption by the photoproduct. Absorbed light intensities were determined by ferrioxalate actinometry. ${ }^{20}$

Progress of the photooxidation was monitored by UV-visible and near-IR spectral measurements with a Varian-Techtron Super Scan 3 recording spectrophotometer and a Zeiss PMQ II spectrophotometer for measurements at selected wavelengths.

The photoproducts $\mathrm{M}\left[\mathrm{S}_{2} \mathrm{C}_{2}(\mathrm{CN})_{2}\right]_{2}^{-}$, with $\mathrm{M}=\mathrm{Ni},{ }^{18} \mathrm{Pd},{ }^{17}$ and $\mathrm{Pt},{ }^{17}$ and $\mathrm{Ni}\left[\mathrm{S}_{2} \mathrm{C}_{2}\left(\mathrm{C}_{6} \mathrm{H}_{5}\right)_{2}\right]_{2}{ }^{16,19}$ were identified by their absorption spectra. The extinction at the maximum of the intense near-IR absorptions were used to determine the concentrations of the photoproducts: $\mathrm{Ni}\left[\mathrm{S}_{2} \mathrm{C}_{2}(\mathrm{CN})_{2}\right]_{2}{ }^{-}, \lambda=848 \mathrm{~nm}(\epsilon=8000) ;{ }^{18} \mathrm{Pd}\left[\mathrm{S}_{2} \mathrm{C}_{2^{-}}\right.$ $\left.(\mathrm{CN})_{2}\right]_{2}{ }^{-}, \lambda=1111 \mathrm{~nm}(\epsilon 13800) ;{ }^{17} \mathrm{Pt}\left[\mathrm{S}_{2} \mathrm{C}_{2}(\mathrm{CN})_{2}\right]_{2}{ }^{-}, \lambda=855 \mathrm{~nm}$ $(\epsilon 11700) ;{ }^{17} \mathrm{Ni}\left[\mathrm{S}_{2} \mathrm{C}_{2}\left(\mathrm{C}_{6} \mathrm{H}_{5}\right)_{2}\right]_{2}, \lambda=866 \mathrm{~nm}(\epsilon 30903) .16$ As indicated by the spectral changes, the photolysis of $\mathrm{M}\left[\mathrm{S}_{2} \mathrm{C}_{2}(\mathrm{CN})_{2}\right]_{2}{ }^{2-}(\mathrm{M}=$ $\mathrm{Pd}, \mathrm{Pt}$ ) and $\mathrm{Ni}\left[\mathrm{S}_{2} \mathrm{C}_{2}\left(\mathrm{C}_{6} \mathrm{H}_{5}\right)_{2}\right]_{2}{ }^{-}$(Figures 1 and 2) took place without

(19) Schrauzer, G. N.; Mayweg, V. P. J. Am. Chem. Soc. 1965, 87, 3585

(20) Hatchard, C. G.; Parker, C. A. Proc. R. Soc. London, Ser. A 1956, 235, 518.
Table I. Photooxidation Quantum Yields $\left(\lambda_{\text {irr }}=313 \mathrm{~nm}\right)$ and Half-Wave Potentials of Oxidation (vs. SCE) of $\left[\mathrm{M}\left(\mathrm{S}_{2} \mathrm{C}_{2} \mathrm{R}_{2}\right)_{2}\right]^{z}$ in $\mathrm{CHCl}_{3}$

\begin{tabular}{ccccc}
\hline metal & ligand & charge $z$ & $\phi(313 \mathrm{~nm})^{a}$ & $E_{1 / 2},{ }^{b} \mathrm{~V}$ \\
\hline $\mathrm{Ni}$ & $\mathrm{S}_{2} \mathrm{C}_{2}(\mathrm{CN})_{2}$ & $2-$ & 0.25 & +0.23 \\
$\mathrm{Pd}$ & & $2-$ & 0.12 & +0.44 \\
$\mathrm{Pt}$ & & $2-$ & 0.23 & +0.21 \\
$\mathrm{Ni}$ & & $1-$ & 0 & +1.02 \\
$\mathrm{Pd}$ & & $1-$ & 0 & $c$ \\
$\mathrm{Pt}$ & & $1-$ & 0 & $c$ \\
$\mathrm{Ni}$ & $\mathrm{S}_{2} \mathrm{C}_{2}\left(\mathrm{C}_{6} \mathrm{H}_{5}\right)_{2}$ & 0 & 0 & $c$ \\
$\mathrm{Pt}$ & & 0 & 0 & $c$ \\
$\mathrm{Ni}$ & & $1-$ & 0.1 & +0.22
\end{tabular}

${ }^{a}$ Experimental error $\pm 5 \%{ }^{b}$ Reference 17. ${ }^{c}$ Not reported but expected to be above $1 \mathrm{~V}$; see ref 11 .

any side reaction. In the case of $\mathrm{Ni}\left[\mathrm{S}_{2} \mathrm{C}_{2}(\mathrm{CN})_{2}\right]_{2}{ }^{2-}$, isosbestic points appeared but were less pronounced, indicating some side reactions. But these side reactions were not important since the quantum yield for product formation and disappearance of the starting complex were equal within $5 \%$.

\section{Results and Discussion}

The most interesting aspect of the chemistry of 1,2-dithiolene complexes is the redox behavior because the ligands themselves can undergo consecutive one-electron-transfer processes while the metal may retain its oxidation state. ${ }^{11}$ The limiting electronic structures of the ligand are the oxidized dithioketone $\mathrm{S}=\mathrm{CRCR}=\mathrm{S}$ and the reduced ethylenedithiolate dianion $-\mathrm{S}-\mathrm{CR}=\mathrm{CR}-\mathrm{S}^{-}$, which has two electrons more. For square-planar complexes of $\mathrm{Ni}, \mathrm{Pd}$, and $\mathrm{Pt}$ in the oxidation state +II, five members of a complete electron-transfer series $\left[\mathrm{M}\left(\mathrm{S}_{2} \mathrm{C}_{2} \mathrm{R}_{2}\right)_{2}\right]^{z}$ with the charges $z=2-$ to $2+$ are feasible. But dependent on the substituent $R$, only neutral and anionic complexes are well characterized. ${ }^{11}$<smiles>[R]C1=C([2H])S[N+]2(S1)SC([R])=C([2H])S2</smiles>

The electronic spectra of 1,2-dithiolene complexes of $\mathrm{Ni}$, Pd, and Pt are very rich. ${ }^{11 a, 16-19}$ The most important orbitals are $2 b_{1 u}$ and $3 b_{2 g}$, which are nondegenerate and essentially ligand-localized $\pi$ orbtials. ${ }^{16,19,21}$ In the neutral complexes with $z=0,3 b_{2 g}$ is empty while the lower $2 b_{1 u}$ is occupied. The allowed transition $2 b_{1 \mathrm{u}} \rightarrow 3 b_{2 \mathrm{~g}}$ gives rise to an intense $a b$ sorption band in the near-infrared regions. This transition is still possible when the charges are $z=1-\left(\right.$ half-filled $3 b_{2 \mathrm{~g}}$ ) and $z=1+$ (half-filled $\left.2 b_{1 u}\right)$. The corresponding absorption is observed for $z=1-$ (Experimental Section and Figure 1). Although cationic 1,2-dithiolene complexes are not stable, this absorption band does occur in the spectra of the similar diimine complexes with $z=1+$ where the sulfur of the dithiolate is replaced by imino groups $\mathrm{NH} .{ }^{10 b}$ These long-wavelength bands are missing in the spectra of the dianionic complexes ${ }^{11 a, 18,19}$ (Figure 1) with $z=2-\left(\right.$ filled $3 b_{2 g}$ ). In addition, many other absorptions occur down to at least $600 \mathrm{~nm}$ irrespective of the charge. The assignment of these bands is controversial. They may be of the ligand field (LF), charge-transfer metal to ligand (CTML) and ligand to metal (CTLM), and intraligand (IL) type. ${ }^{14,16,18,19,21,22}$ They should occur at widely differing energies depending on the metal, the substituent $R$ at the dithiolene ligand, and the charge $z$.

Fortunately, the interpretation of our results does not depend on the assignments of the absorption bands since the light sensitivity of those complexes which are photooxidized is es-

(21) Schrauzer, G. N. Acc. Chem. Res. 1969, 2, 72

(22) Clark, R. J. H.; Turtle, P. C. J. Chem. Soc., Dalton Trans. 1977, 2142. 
Table II. Half-Wave Potentials of Oxidation of Complexes Which Are Photooxidized in Halocarbon Solvents

\begin{tabular}{|c|c|}
\hline complex & $E_{1 / 2}, \mathrm{~V}$ (vs. SCE) \\
\hline $\begin{array}{l}\mathrm{Fe}\left(\eta^{5}-\mathrm{C}_{5} \mathrm{H}_{5}\right)_{2}{ }^{a} \\
{\left[\mathrm{Fe}\left(\eta^{5}-\mathrm{C}_{5} \mathrm{H}_{5}\right)(\mathrm{CO})\right]_{4}{ }^{b}} \\
\mathrm{Fe}\left[\mathrm{S}_{2} \mathrm{CN}\left(\mathrm{C}_{2} \mathrm{H}_{5}\right)_{2}\right]_{3}{ }^{\mathrm{C}} \\
\mathrm{Ni}(\mathrm{O}-\mathrm{phen})\left[\mathrm{S}_{2} \mathrm{C}_{2}\left(\mathrm{C}_{6} \mathrm{H}_{5}\right)_{2}\right]^{d} \\
\mathrm{Ni}\left[(\mathrm{NH})_{2} \mathrm{C}_{6} \mathrm{H}_{4}\right]_{2} e^{2} \\
\mathrm{Pd}\left[(\mathrm{NH})_{2} \mathrm{C}_{6} \mathrm{H}_{4}\right]_{2}{ }^{e} \\
\operatorname{Pt}\left[(\mathrm{NH})_{2} \mathrm{C}_{6} \mathrm{H}_{4}\right]_{2}^{e}\end{array}$ & $\begin{array}{l}+0.39^{f} \\
+0.32^{f} \\
+0.4^{c} \\
+0.33^{g} \\
+0.14^{h} \\
+0.10^{h} \\
+0.23^{h}\end{array}$ \\
\hline
\end{tabular}

sentially restricted to wavelengths between 300 and $350 \mathrm{~nm}$ regardless of the metal, the substituent $R$, and the charge $z$.

While in most solvents, e.g., acetonitrile, all complexes investigated in the present study are not light sensitive, some of them are oxidized with high quantum yields upon irradiation with light of wavelengths $300-350 \mathrm{~nm}$, when dissolved in $\mathrm{CHCl}_{3}$ (Table I). By analogy with other photooxidations in halocarbon solvents, our results are consistent with eq 1 ,

$$
\begin{aligned}
{\left[\mathrm{M}\left(\mathrm{S}_{2} \mathrm{C}_{2} \mathrm{R}_{2}\right)_{2}\right]^{2}+\underset{ }{\mathrm{CHCl}} \rightarrow } & \left.\mathrm{M}_{3}\left(\mathrm{~S}_{2} \mathrm{C}_{2} \mathrm{R}_{2}\right)_{2}\right]^{2+1}+\mathrm{Cl}^{-}+\cdot \mathrm{CHCl}_{2}
\end{aligned}
$$

While the one-electron oxidation product of the complex is stable, the $\cdot \mathrm{CHCl}_{2}$ radical may undergo secondary reactions.

The electronic structures and hence the electronic transitions of all complexes which undergo the photooxidation are so different that any common explanation seems to be impossible. However, a careful survey of the published data shows that all photoactive complexes are oxidized at low potentials in the same region $\left(E_{1 / 2}=0.1-0.5 \mathrm{~V}\right.$ vs. SCE; see Table I). It follows that the photooxidation is controlled only thermodynamically and occurs regardless of the type and energy of the intramolecular absorption bands displayed by any particular complex. Those complexes which are oxidized at potentials below $0 \mathrm{~V}$ are subject to air oxidation ${ }^{11 a}$ and were not included in the present study. They are also expected to be photooxidized at irradiating wavelengths longer than $350 \mathrm{~nm}$. Those complexes which are oxidized above $0.5 \mathrm{~V}$, e.g., $\mathrm{M}\left[\mathrm{S}_{2} \mathrm{C}_{2}(\mathrm{CN})_{2}\right]_{2}{ }^{-}(\mathrm{M}=$ $\mathrm{Ni}, \mathrm{Pd}, \mathrm{Pt})$ and $\mathrm{M}\left[\mathrm{S}_{2} \mathrm{C}_{2}\left(\mathrm{C}_{6} \mathrm{H}_{5}\right)_{2}\right]_{2}(\mathrm{M}=\mathrm{Ni}, \mathrm{Pt})$ were not observed to be photosensitive. They are expected to be photooxidized with light of wavelengths shorter than $300 \mathrm{~nm}$. Unfortunately, $\mathrm{CHCl}_{3}$ absorbs in this region.

It is interesting to note that a variety of other complexes which are photooxidized between 300 and $350 \mathrm{~nm}$ are also oxidized at potentials between 0.1 and $0.5 \mathrm{~V}$ vs. SCE. Some of them are related to the 1,2-dithiolene complexes, and others are completely different (Table II). In some cases these complexes displayed CTTS absorption bands when dissolved in halocarbon solvents. $5,6,9$ Photooxidation may then be due to light absorption into CTTS bands.

We searched for the presence of CTTS bands by measuring the difference spectra in acetonitrile and $\mathrm{CHCl}_{3}$. In the case of $\mathrm{Pt}\left[\mathrm{S}_{2} \mathrm{C}_{2}(\mathrm{CN})_{2}\right]_{2}{ }^{2-}$, careful measurements revealed two new maxima at 318 and $363 \mathrm{~nm}$. For $\mathrm{Ni}\left[\mathrm{S}_{2} \mathrm{C}_{2}(\mathrm{CN})_{2}\right]_{2}{ }^{2-}$ there was an indication of a less well-pronounced new band around 335 $\mathrm{nm}$. However, all our complexes have very intense intramolecular absorptions $(\epsilon \sim 20000)$ in the $300-350-\mathrm{nm}$ region. Hence any other absorption of much lower intensity may be obscured. In addition, any weak new absorption detected by difference spectroscopy in two solvents may be artificial and due to any unspecified solvent shift. But irrespective of the

(23) Ferguson, J. A.; Meyer, T. J. J. Chem. Soc., Chem. Commun. 1971 623; J. Am. Chem. Soc. 1972, $94,3409$.

(24) Miller, T. R.; Dance, I. G. J. Am. Chem. Soc. 1973, 95, 6970

(25) Balch, A. L.; Holm, R. H. J. Am. Chem. Soc. 1966, 88, 5201
Table III. Wavelength Dependence ${ }^{a}$ of Photooxidation Quantum Yields of $\mathrm{M}\left[\mathrm{S}_{2} \mathrm{C}_{2}(\mathrm{CN})_{2}\right]_{2}{ }^{2-}$ in $\mathrm{CHCl}_{3}$

\begin{tabular}{ccccc}
\hline metal & $\lambda=313$ & $\lambda=333$ & $\lambda=366$ & $\lambda=405$ \\
\hline $\mathrm{Ni}$ & 0.25 & 0.10 & 0.013 & 0.001 \\
$\mathrm{Pd}$ & 0.12 & 0.045 & 0.007 & 0.001 \\
$\mathrm{Pt}$ & 0.23 & 0.075 & 0.038 & 0.009 \\
${ }^{a} \lambda_{\text {irr }}$ given in nm. & $b$ Experimental error $\pm 5 \%$. &
\end{tabular}

presence of CTTS bands, most of the light causing photooxidation of the 1,2-dithiolene complexes is certainly absorbed by bands of a different origin.

The energy of the CTTS state should depend not only on the redox potential of the complex but also on that of the solvent. The photoactive wavelength region is expected to shift to the red with increasing oxidizing power of the solvent. The photoactive wavelength region is expected to shift to the red with increasing oxidizing power of the solvent. This assumption was confirmed. In addition to $\mathrm{CHCl}_{3}\left(E_{1 / 2}=-1.67\right.$ $\mathrm{V}$ vs. $\left.\mathrm{SCE}^{26}\right)$ as solvent, the complex $\mathrm{Ni}\left[\mathrm{S}_{2} \mathrm{C}_{2}(\mathrm{CN})_{2}\right]_{2}{ }^{2-}$ was also photolyzed in $\mathrm{CH}_{2} \mathrm{Cl}_{2}\left(E_{1 / 2}=-2.33 \mathrm{~V}^{26}\right)$ and $\mathrm{CCl}_{4}\left(E_{1 / 2}\right.$ $\left.=-0.78 \mathrm{~V}^{26}\right)$. The quantum yield $\left(\lambda_{\text {irr }}=366 \mathrm{~nm}\right)$ of photooxidation increased from $\phi=0.002$ in $\mathrm{CH}_{2} \mathrm{Cl}_{2}$ to $\phi=0.013$ in $\mathrm{CHCl}_{3}$ and $\phi=0.07$ in $\mathrm{CCl}_{4}$. While $366-\mathrm{nm}$ light leads to a fairly efficient population of the reactive CTTS state in $\mathrm{CCl}_{4}$, it is apparently not sufficient to reach this state at higher energies in $\mathrm{CH}_{2} \mathrm{Cl}_{2}$ as solvent. Such a solvent dependence was also observed for the photooxidation of $\left[\eta^{5}-\mathrm{C}_{5} \mathrm{H}_{5} \mathrm{Fe}(\mathrm{CO})\right]_{4} \cdot{ }^{6}$

Shirom et al. investigated extensively the photooxidation of cyanide complexes in aqueous solution with concomitant formation of solvated electrons. ${ }^{4}$ They concluded that in the main pathway the electron is ejected to the solvent from CTTS excited states. These states can be reached by direct light absorption into a CTTS band or by internal conversion from other excited states. Even when a CTTS band was not detected, an efficient production of solvated electrons was observed. Consequently, the quantum yield of photooxidation does not depend on the fraction of light absorbed by a CTTS band. It was suggested that the reaction from the CTTS state is an extremely rapid process which competes successfully with other modes of deactivation. We assume that the same mechanism applies to the photooxidation of 1,2-dithiolene complexes of $\mathrm{Ni}, \mathrm{Pd}$, and Pt. The energy of the CTTS state depends only on the redox potentials of the complex and the solvent. It may be populated by an efficient internal conversion from any higher intramolecular excited state. The photooxidation takes place before a deactivation to lower excited states that are nonreactive occurs.

A further point of interest is the observation that the quantum yield of photooxidation increases with decreasing wavelength of irradiation (Table III). This behavior seems to be characteristic for the reactivity of CTTS excited states. Shirom et al. suggested that the electron ejection is rapid enough to occur from higher vibrational levels of the CTTS excited state. ${ }^{27,28}$ Such a hot excited-state mechanism may account for the observed wavelength dependence.

In addition to the photooxidation starting from CTTS states, it was concluded that also other excited states, particularly of the CTML type, can lead to the release of an electron. ${ }^{29}$ These reactions seem to be much slower processes. The photooxidation of isocyanide complexes of $\mathrm{Cr}$, Mo, and $\mathrm{W}$ may belong to this category. ${ }^{7}$ Light absorption by the long-

(26) $E_{1 / 2}$ values from: Mann, C. K.; Barnes, K. K. "Electrochemical Reactions in Nonaqueous Systems"; Marcel Dekker: New York, 1970.

(27) Shirom, M.; Weiss, M. J. Chem. Phys. 1972, 56, 3170

(28) Shirom, M.; Siderer, Y. J. Chem. Phys. 1973, 58, 1250.

(29) Moan, J.; Shirom, M.; Weiss, M. Isr. J. Chem. 1973, I1, 21 
wavelength CTML bands ( $436 \mathrm{~nm}$ ) of these complexes dissolved in inert solvents is followed by an emission from CTML excited states. In $\mathrm{CHCl}_{3}$ this emission was quenched with simultaneous oxidation of the complexes. A further example of this type is apparently the photooxidation of $\left(2,2^{\prime}\right.$-bipyridine)(3,4-toluenedithiolato)platinum(II) in $\mathrm{CHCl}_{3}$ following charge-transfer ligand-to-ligand (CTLL) excitation at long wavelength $(577 \mathrm{~nm}){ }^{10 \mathrm{C}}$ It is interesting to note that the similar complex $\mathrm{Ni}^{\mathrm{II}}$ (phen) $\left[\mathrm{S}_{2} \mathrm{C}_{2}\left(\mathrm{C}_{6} \mathrm{H}_{5}\right)_{2}\right]$ (phen $=1,10$ phenanthroline) is photooxidized in $\mathrm{CHCl}_{3}$ only by shortwavelength irradiation $(\lambda<350 \mathrm{~nm})$, while the CTLL band at longer wavelength is not photoactive. ${ }^{10 d}$ Compared to the $\mathrm{Pt}$ complex, the Ni compound should have LF excited states at much lower energies which can quench the CTLL state. In distinction, the CTTS excited states at higher energies react so rapidly that other lower excited states apparently do not interfere.

Acknowledgment. Financial support for this research by the Deutsche Forschungsgemeinschaft and the Fonds der Chemischen Industrie is gratefully acknowledged.

Registry No. $\left[\mathrm{Ni}\left(\mathrm{S}_{2} \mathrm{C}_{2}(\mathrm{CN})_{2}\right)_{2}\right]^{2-}, 14876-79-0 ;\left[\mathrm{Pd}\left(\mathrm{S}_{2} \mathrm{C}_{2}(\mathrm{CN})_{2}\right)_{2}\right]^{2-}$ 19555-33-0; $\left[\mathrm{Pt}\left(\mathrm{S}_{2} \mathrm{C}_{2}(\mathrm{CN})_{2}\right)_{2}\right]^{2-}, 15152-99-5 ;\left[\mathrm{Ni}\left(\mathrm{S}_{2} \mathrm{C}_{2}(\mathrm{CN})_{2}\right)_{2}\right]^{-}$, 46761-25-5; $\left[\mathrm{Pd}\left(\mathrm{S}_{2} \mathrm{C}_{2}(\mathrm{CN})_{2}\right)_{2}\right]^{-}, 19570-29-7 ;\left[\mathrm{Pt}\left(\mathrm{S}_{2} \mathrm{C}_{2}(\mathrm{CN})_{2}\right)_{2}\right]^{-;}$, 14977-45-8; $\mathrm{Ni}\left(\mathrm{S}_{2} \mathrm{C}_{2}\left(\mathrm{C}_{6} \mathrm{H}_{5}\right)_{2}\right)_{2}, 28984-20-5 ; \mathrm{Pt}\left(\mathrm{S}_{2} \mathrm{C}_{2}\left(\mathrm{C}_{6} \mathrm{H}_{5}\right)_{2}\right)_{2}$, 15607-55-3; $\left[\mathrm{Ni}\left(\mathrm{S}_{2} \mathrm{C}_{2}\left(\mathrm{C}_{6} \mathrm{H}_{5}\right)_{2}\right)_{2}\right]^{-}, 14879-11-9$.

\title{
High-Pressure Mechanistic Studies of the Photochemical Reactions of Transition-Metal Complexes. 3. Medium Effects on the Photoaquation of Some $\mathrm{Co}$ (III) and $\mathrm{Cr}$ (III) Complexes in Solution
}

\author{
K. ANGERMANN, R. SCHMIDT, R. vAN ELDIK,* H. KELM,* and F. WASGESTIAN'
}

\section{Received September 18, 1981}

The viscosity dependence of the photoaquation reactions of $\mathrm{Co}(\mathrm{CN})_{6}{ }^{3-}, \mathrm{Cr}(\mathrm{CN})_{6}{ }^{3-}, \mathrm{Cr}(\mathrm{NCS})_{6}{ }^{3-}, \mathrm{Cr}\left(\mathrm{NH}_{3}\right)_{5} \mathrm{NCS}^{2+}$, and $\mathrm{Cr}\left(\mathrm{NH}_{3}\right)_{6}{ }^{3+}$ was studied in glycerol/water mixtures $(\leq 65 \mathrm{wt} \%)$ at normal pressure. The results indicate that significant cage recombination occurs during the photosubstitution of $\mathrm{NH}_{3}$ in $\mathrm{Cr}\left(\mathrm{NH}_{3}\right)_{5} \mathrm{NCS}^{2+}$ and $\mathrm{Cr}\left(\mathrm{NH}_{3}\right)_{6}{ }^{3+}$ in pure water. However, no significant cage effect was observed in the photosubstitution of $\mathrm{CN}^{-}$and $\mathrm{NCS}^{-}$in the studied systems. In addition, the combined medium-pressure dependence of the photoaquation of $\mathrm{NCS}^{-}$in $\mathrm{Cr}\left(\mathrm{NH}_{3}\right)_{5} \mathrm{NCS}^{2+}$ was studied over the ranges $1 \leq p \leq 1500$ bar and $1<\eta<30 \mathrm{cP}$. A rather unexpected pressure dependence of the quantum yield is reported for this reaction in highly viscous media. The results are discussed in reference to data reported in the literature.

\section{Introduction}

The earlier papers in this series ${ }^{2,3}$ concerned high-pressure mechanistic studies of the ligand field photolysis of some cationic $\mathrm{Cr}$ (III) ammine and some anionic pseudohalogeno $\mathrm{Co}$ (III) and $\mathrm{Cr}$ (III) complexes in aqueous solution. From the pressure dependence of the observed quantum yields for the photoaquation processes, apparent volumes of activation were calculated. These data permitted a detailed discussion of the molecular nature of the intimate mechanism involved in such photoaquation reactions.

It was concluded ${ }^{2}$ that reactions of the type

$$
\begin{gathered}
\mathrm{Cr}\left(\mathrm{NH}_{3}\right)_{5} \mathrm{X}^{2+}+\mathrm{H}_{2} \mathrm{O} \stackrel{h_{\nu}}{\longrightarrow} \mathrm{Cr}\left(\mathrm{NH}_{3}\right)_{5} \mathrm{OH}_{2}{ }^{3+}+\mathrm{X}^{-} \\
\mathrm{X}=\mathrm{Cl}, \mathrm{Br}, \mathrm{NCS}
\end{gathered}
$$

proceed according to an $I_{a}$ mechanism, during which substantial $\mathrm{Cr}-\mathrm{X}$ bond cleavage occurs in the transition state. Furthermore, reactions of the type

$\mathrm{Cr}\left(\mathrm{NH}_{3}\right)_{5} \mathrm{X}^{n+}+\mathrm{H}_{2} \mathrm{O} \stackrel{h \nu}{\rightarrow}$ cis- $\mathrm{Cr}\left(\mathrm{NH}_{3}\right)_{4}\left(\mathrm{OH}_{2}\right) \mathrm{X}^{n+}+\mathrm{NH}_{3}$

$$
n=2 \text { for } \mathrm{X}=\mathrm{Cl}, \mathrm{Br}, \mathrm{NCS} ; n=3 \text { for } \mathrm{X}=\mathrm{NH}_{3}
$$

also follow such a mechanism but with significantly less $\mathrm{Cr}-$ $\mathrm{NH}_{3}$ bond cleavage in the transition state. In contrast, it was found ${ }^{3}$ that reactions of the type

(1) Institut für Anorganische Chemie der Universität Köln

(2) Angermann, K.; van Eldik, R.; Kelm, H.; Wasgestian, F. Inorg. Chem. 1981, 20,955.

(3) Angermann, K.; van Eldik, R.; Kelm, H.; Wasgestian F. Inorg. Chim Acta 1981, 49, 247

$$
\begin{gathered}
\mathrm{ML}_{6}{ }^{3-}+\mathrm{H}_{2} \mathrm{O} \stackrel{h_{\nu}}{\longrightarrow} \mathrm{ML}_{5}\left(\mathrm{OH}_{2}\right)^{2-}+\mathrm{L}^{-} \\
\mathrm{M}=\mathrm{Co}(\mathrm{III}) \text { for } \mathrm{L}=\mathrm{CN} \\
\mathrm{M}=\mathrm{Cr}(\mathrm{III}) \text { for } \mathrm{L}=\mathrm{NCS}, \mathrm{CN}
\end{gathered}
$$

proceed according to an $\mathrm{I}_{\mathrm{d}}$ mechanism in which some $\mathrm{M}-\mathrm{OH}_{2}$ bond formation occurs in the transition state.

Scandola et al. ${ }^{4,5}$ followed a different approach. They studied medium effects on the photoaquation of $\mathrm{Co}(\mathrm{CN})_{6}^{3-}$ and presented evidence for the occurrence of cage recombination in such photosubstitution reactions. The viscosity of the solvent had a meaningful influence on the quantum yield of the aquation reaction, and a good correlation between these variables was reported. The cage effect seemed to be quite efficient in more viscous solvents but relatively unimportant in pure aqueous solution for the studied system. Scandola et al. concluded that these tendencies may not hold for other photosubstitution reactions and are expected to depend on the nature of the leaving group. ${ }^{5}$

Wong and Kirk ${ }^{6}$ observed similar viscosity effects for the photoaquation of $\mathrm{Co}(\mathrm{CN})_{6}{ }^{3-}$ in water/glycerol, water/ethylene glycol, and water/ethanol mixtures. In contrast, however, they ${ }^{6}$ argued that cage recombination is not established by their data since they do not find such an effect in water/acetonitrile and water/poly(vinylpyrrolidone) mixtures. Alternative explanations such as changes in the extent of solvent structure ${ }^{7}$

(4) Scandola, F.; Bartocci, C.; Scandola, M. A. J. Am. Chem. Soc. 1973 95, 7898 .

(5) Scandola, F.; Scandola, M. A.; Bartocci, C. J. Am. Chem. Soc. 1975 97,4757 .

(6) Wong, C. F. C.; Kirk, A. D. Can. J. Chem. 1976, 54, 3794. 